О. М. Олещук, Г. Я. Лой

\title{
Механізми реалізації кардіопротективних ефектів метформіну (огляд літератури)
}

Тернопільський національний медичний університет ім. І. Я. Горбачевського Міністерства охорони здоров'я України

Ключові слова: метформін, діабетична кардіоміопатія, інфаркт міокарда, кардіальна автономна нейропатія

Цукровий діабет (ЦД) $є$ основною причиною пандемічного зростання кількості мікро- та макросудинних ускладнень, що є соціальним та економічним тягарем у всьому світі. Ця хвороба вражає практично всі тканини в організмі та викликає виражену дисфункцію органів [1].

ЦД є незалежним фактором виникнення ураження міокарда [2]. Серед смертності від серцево-судинних захворювань понад $65 \%$ становлять випадки, що пов'язані з ЦД [1].

ЦД асоційований із найвагомішими факторами ризику серцевої недостатності $(\mathrm{CH})$, включаючи ожиріння, гіперліпідемію, гіперхолестеринемію, тромбоз, інфаркт, гіпертензію, активацію гормональної та цитокінової систем, автономну нейропатію, ендотеліальну дисфункцію й ішемічну хворобу серця [2]. Як результат, хворі на діабет мають значно гірший прогноз щодо наслідків $\mathrm{CH}$, ніж пацієнти без діабету [3].

Метформін, препарат першої лінії для стартової фармакотерапії ЦД 2 типу, має високий профіль безпеки та може зменшувати ризик виникнення кардіоваскулярних ускладнень і зумовленої ними смертності [4]. Метформін покращує чутливість рецепторів до інсуліну та зменшує інсулінорезистентність, яка $є$ провідною патофізіологічною ланкою розвитку ЦД 2 типу. Такий ефект можна пояснити позитивним впливом препарату на експресію рецепторів інсуліну та активність тирозинкінази. Основна роль відводиться здатності препарату зменшувати продукцію глюкози печінкою шляхом при-

(C) Колектив авторів, 2020 гнічення глюконеогенезу [5]. Як наслідок, знижується маса тіла, гіперінсулінемія та гіперглікемія, сповільнюється трансформація порушеної толерантності до глюкози або попереджається іï розвиток [6].

Відомо, що позитивний ефект препарату на діяльність серця зумовлений прямим впливом на клітинний метаболізм, ендотеліальну функцію, активність тромбоцитів і гомеостаз кальцію [7]. Встановлено, що метформін модулює фактори ризику атеросклерозу, підвищує толерантність міокарда до ішемії-реперфузії та попереджує розвиток $\mathrm{CH}$ [2].

Сьогодні залишаються до кінця нез'ясованими механізми реалізації кардіопротективних властивостей метформіну, а наявні дані проведених досліджень $є$ часто суперечливими.

Мета дослідження - провести аналіз результатів досліджень, присвячених вивченню протективної дії метформіну в діабетичному міокарді.

Механізми ураження міокарда за ЦД. Клінічно ураження серця за діабету найчастіше проявляється у вигляді діабетичної кардіоміопатії (ДКМ), кардіальної автономної нейропатії (КАН) та ішемічної хвороби серця й, як наслідок, інфаркту міокарда (IM) [1].

Діабетична кардіоміопатія. ДКМ є однією з основних причин термінальної стадії $\mathrm{CH}$, що часто призводить до раптової зупинки серця та смерті [8]. Ïї розвиток є багатофакторним і включає такі механізми, як метаболічні порушення, резистентність до інсуліну, мікросудинні ураження, зміни в системі ренін-ангіотензину, вегетативна дисфункція серця та фіброз міокарда [9].

ДКМ гістологічно характеризується апоптозом, гіпертрофією та фіброзом, 
функціонально - кардіальною дисфункцією, що виникають незалежно від судинних чи серцевих захворювань [10], та обумовлена втратою кардіоміоцитів внаслідок мікросудинного спазму та реперфузійного пошкодження 3 подальшим розвитком фокального фіброзу та реактивної гіпертрофії у відповідь на некроз міокарда [9].

Вважається, що хронічна гіперглікемія відіграє центральну роль у розвитку цієї патології, адже посилений нею метаболізм глюкози призводить до надмірного утворення активних форм кисню в мітохондріях [11], які окиснюють цитоплазматичні ліпіди в ліпідні пероксиди та викликають пошкодження клітин і мітохондрій, а також порушують мітохондріальний окиснювальний метаболізм [12]. Надмірна продукція супероксиду мітохондріальним дихальним ланцюгом викликає зниження скоротливої здатності міокарда, що, зрештою, веде до фіброзу кардіоміоцитів [13], пошкодження ДНК і пришвидшеного апоптозу кардіоміоцитів [1].

Сьогодні не існує специфічних терапевтичних стратегій, спрямованих на лікування ДКМ, тому подальше дослідження молекулярних основ розвитку даної патології та пошук лікарських засобів, які могли б впливати на ці механізми, залишається актуальною проблемою сучасної фармакології [1].

Інфаркт ліокарда. Популяційні дослідження встановили, що IM у хворих на діабет виникає достовірно частіше, ніж у пацієнтів без ЦД [14]. Більше того, наслідки інфаркту в таких пацієнтів є значно важчими, що підвищує ризик його повторного виникнення та смерті [15].

Постінфарктні структурні зміни в серці, які об’єднують під терміном "ремоделювання міокарда», включають гіпертрофію, інтерстиціальний фіброз, прогресуюче стоншення стінок і дилатацію камери шлуночка, які врешті призводять до прогресування кардіальної дисфункції та СН [16]. До того ж виникають порушення регуляції нейрогуморальних сигнальних шляхів, тому окрім кардіоміоцитів до патогенезу ремоделювання залучаються фібробласти, ендотеліоцити та клітини імунного захисту [17]. Ремоделювання міокарда, що $€$ наслідком інфаркту, розпочинається швидко, у перші години, і триває від кількох тижнів до місяців, а його обсяг корелює 3 розміром зони некрозу та залежить від якості лікувальної тактики [18].

Розмір зони некрозу є основною детермінантою надмірного ремоделювання, хоча неабияке значення відіграють також навантаження на шлуночок та якісні характеристики процесу загоєння рани. Наприклад, пролонгована активація постінфарктного запалення підвищує активність протеаз та асоціюється з надмірною дилатацією [19], підвищеною жорсткістю шлуночка та діастолічною дисфункцією [20]. Пацієнти з масивним ремоделюванням міокарда мають вищий ризик виникнення аритмій, $\mathrm{CH}$ і раптової смерті після IM [21]. Крім того, неабияку роль у прогресуванні шлуночкового ремоделювання та $\mathrm{CH}$ відіграє стрес-індукована реактивація фетальних генів у пошкодженому міокарді [22].

Із кожним роком рівень виживання пацієнтів після IM зростає, проте спостерігається тенденція до більшої поширеності СН [23]. Це зумовлено тим, що сучасні підходи до IM є переважно паліативними та не спрямовані на попередження фундаментальної проблеми ремоделювання міокарда [24]. Тому реверсія ремоделювання міокарда $\epsilon$ ключовою терапевтичною стратегією, щоб сповільнити прогресування $\mathrm{CH}$ i зменшити смертність внаслідок IM [16].

Кардіальна автонолна нейропатія. КАН $€$ доволі частим ускладненням ЦД, що має значимий вплив на якість життя та асоціюється з несприятливим прогнозом. Виникнення цієї патології зумовлене пошкодженням автономних нервових волокон, що іннервують серце та кровоносні судини, а це призводить до важких порушень серцево-судинної динаміки [25]. Гіперглікемію вважають пусковим механізмом таких патологічних змін [26].

У зв'язку з домінуючим ураженням блукаючого нерва виникає тахікардія в стані спокою, адже за таких умов серце зазнає надмірного впливу симпатичної нервової системи. Підвищена частота серцевих скорочень утримується навіть 
вночі, тому пацієнти 3 КАН більш схильні до розвитку гіпертрофії міокарда та кардіальної дисфункції [27].

3 часом відбувається маніфестація таких симптомів, як порушення толерантності до фізичних навантажень, ортостатична гіпотензія та надмірне обмеження варіабельності серцевого ритму. До того ж погіршується сприйняття серцевого болю через пошкодження чутливих нервів, тому симптоми «німої» ішемії міокарда не розпізнаються пацієнтом вчасно [28].

У пацієнтів з діабетичною КАН надмірна симпатична стимуляція веде до активації ренін-ангіотензин-альдостеронової системи, що, попри тахікардію, сприяє збільшенню периферичного судинного опору. Поєднання симпатичної гіперактивності та регіональної симпатичної денервації в міокарді провокує зменшення резерву коронарного кровотоку та діастолічну, а згодом i систолічну дисфункцію [29].

Відомо, що кардіальна денервація на початкових етапах може бути зворотною, тому рання діагностика та вчасне лікування можуть покращати прогноз пацієнта [29]. Оптимізацію метаболічного профілю вважають єдиною ефективною стратегією лікування діабетичної КАН [30].

Оскільки компенсація ЦД досягається далеко не в усіх пацієнтів, є необхідність у пошуку лікарського засобу, який би зменшував прояви КАН, зокрема, протидіючи надмірним впливам симпатичної нервової системи.

Кардіопротективні ефекти летформіну та механізли їхньої реалізації. У своєму дослідженні Evans і співавт. продемонстрували, що в пацієнтів з ЦД 2 типу та $\mathrm{CH}$, які приймали метформін або його комбінацію з препаратами сульфонілсечовини, спостерігався значно нижчий рівень смертності порівняно 3 тими, хто отримував монотерапію препаратами сульфонілсечовини [31]. Інша група вчених Aguilar і співавт. підтвердила, що виживання пацієнтів, які отримували терапію метформіном, було суттєво вищим [32]. У своєму дослідженні Romero та співавтори [33] продемонстрували, що в пацієнтів з ЦД і СН лікування метформіном асоціюється з нижчими рівнями смертності та госпіталізації.

Мета-аналіз когортних досліджень підтвердив, що ефект метформіну, порівняно 3 іншими гіпоглікемічними препаратами, характеризується зниженням рівня смертності та кількості госпіталізацій серед пацієнтів, хворих на ЦД із СН, різними класами дисфункцій нирок та показниками фракцій викиду [34].

Дослідження UKPDS показало, що лікування метформіном, попри схожі 3 іншими цукрознижуючими засобами показники глікемічного контролю, асоціюється зі зменшенням рівня загальної смертності та смерті від ЦД, а також з нижчим ризиком IM [35]. Важливим $€$ той факт, що позитивний вплив метформіну утримувався навіть через 10 років після проведення досліджень [4]. У дослідженні SPREADDIMCAD виявлено, що пацієнти з ЦД 2 типу та кардіоваскулярними захворюваннями, ліковані метформіном, мали на 46 \% менший показник серцево-судинних ускладнень порівняно 3 тими, хто отримував гліпізид [36].

Здатність метформіну пригнічувати синтез протеїнів у кардіоміоцитах, зменшувати серцеву масу та експресію прогіпертрофічних цитокінів обгрунтовує його терапевтичну ефективність за кардіальної гіпертрофії [37].

Раніше було встановлено, що метформін ефективно зменшує гіпертрофію, викликану поперечним звуженням аорти [38] та ін'єкціями ізопротеренолу [37]. Інша група дослідників [39] у дослідженні in vitro виявила, що метформін захищає кардіоміобласти ембріонів щурів (Н9C2 клітини) від ушкодження, викликаного гіпоксією та гіперглікемією. Встановлено здатність метформіну запобігати гіпертрофії та апоптозу Н9C2 клітин, викликаних інкубацією з 2DG або обмеженим доступом кисню [40].

Метформін пригнічує оксидативний стрес і запалення як прямо, так і опосередковано. Більше того, він зменшує метаболічне перевантаження клітин та індуковане інсулінорезистентністю запалення в тканинах і діє безпосередньо на моноцити, гальмуючи їхнє диференціювання в макрофаги [41]. 
Метформін пригнічуе прозапальні реакції макрофагів і сприяє їхній диференціації до протизапального функціонального фенотипу [42]. Препарат інгібуе маркери запалення, запобігаючи супутньому посиленню оксидативного метаболізму [43]. Зменшення продукції реактивних форм кисню пов'язане з гальмуванням протеїнкінази C і комплексу 1 респіраторного дихального ланцюга [44].

Наявні дані, що метформін може втручатися в ренін-ангіотензин-альдостеронову систему, індукуючи АМРК, внаслідок чого пригнічується синтез ангіотензину II. Крім того, препарат знижує фіброгенез через зменшення продукції цитозолем активних форм кисню [45].

М. Нu та співавт. [39] у дослідженні in vitro виявили, що метформін захищає кардіоміоцити ембріонів щурів від ушкодження, викликаного гіпоксією та гіперглікемією. Кардіопротективний ефект препарату in vitro був реалізований через AMPK/JNK-залежний механізм.

АМРК є основним медіатором у реалізації фармакологічних властивостей метформіну [46]. Утім, сьогодні все більш очевидним є той факт, що цей фермент - далеко не єдина мішень у механізмі дії метформіну, і препарат може проявляти свої ефекти незалежно від його активності. Зокрема, групою науковців 3'ясовано, що блокування гена AMPK 2 у мишей не вплинуло на здатність метформіну проявляти кардіопротекцію [47].

У літературі описано, що метформін діє в ендотеліальних клітинах [48], у гепатоцитах [49], у клітинах злоякісних пухлин ендометрію шляхом регуляції активності транскрипційного білка forkhead box O1 (FoxO1), який кодується однойменним геном [50]. Встановлено також, що FoxO1 відіграє неабияку роль у підтримці кардіального гомеостазу [51], проте немає даних щодо впливу препарату на експресію цих генів і білків у серці.

FoxO - група протеїнів, що включає FoxO1, FoxO3a, FoxO4 та FoxO6, які забезпечують різноманітні функції, регулюючи експресію генів, пов'язаних 3 апоптозом, зупинкою клітинного циклу, репарацією пошкодженої ДНК, метаболізмом глюкози, стійкістю до оксиснювального стресу та іншими функціями [52].

Метформін інгібує стрес-активовану апоптичну загибель Н9C2 клітин через FoxO1-залежний механізм, оскільки за нормальної функції гена FoxO1 препарат ефективно запобігає програмованій загибелі Н9С2 клітин, однак у випадку їхньої трансфекції за допомогою siРНК FoxO1 здатність попереджувати програмовану загибель кардіоміобластів, індуковану гіпоксією-реоксигенацією, втрачається [40].

Мета-аналізи спостережних досліджень підтверджують, що метформін пов'язаний зі зниженим ризиком IM порівняно з препаратами сульфонілсечовини [53]. У хворих на ЦД та гострий IM, які отримували метформін, порівняно із нелікованими метформіном пацієнтами, спостерігали зниження пікових значень маркерів смертності кардіоміоцитів. Це саме дослідження показало, що в пацієнтів з ЦД 2 типу, які отримували метформін, розміри зон інфаркту були меншими, ніж у пацієнтів без ЦД, які не приймали препарат [54]. За моделювання IM у мишей введення метформіну безпосередньо перед ішемією або в період реперфузії сприяло значному зменшенню зони інфаркту [55]. Важливо, що кардіопротективні ефекти метформіну за ішемії-реперфузії продемонстровані як на моделях тварин 3 діабетом [56], так і без нього [54].

Раніше групою авторів [55] було встановлено, що метформін регулює процеси апоптозу в ізольованих кардіоміоцитах як через каспаза 3 -залежний шлях, так і незалежно від нього. У дослідженні [52] встановлено, що метформін дозозалежно посилює експресію антиапоптичного внутрішньоклітинного білкового фактора Bcl2 у гепатоцитах. В іншій роботі описано, що метформін захищає фібробласти шкіри людини від апоптозу, зменшуючи експресію протеїнів Вах і підвищуючи $\mathrm{Bcl} 2$, що веде до зростання співвідношення Bcl-2/Bax [57]. Група дослідників [58] виявила, що метформін зменшує фіброз, інгібуючи надмірну експресію генів COL1A1 і TGF- $\beta 1$, зумовлену IM у мишей. 
Метформін зменшує ізопротереноліндуковану гіпертрофію кардіоміоцитів i запобігає ізопротеренол-індукованій ап-регуляції профібротичних генів [37]. Лікування метформіном у дозі 100 мг/ кг пригнічує гіпертрофічну відповідь міокарда за моделювання ізопротеренолової кардіоміопатії в щурів, що супроводжувалося достовірно нижчою концентрацією сироваткового BNP [59].

Результати проведеного нами дослідження дозволили встановити, що метформін проявляє виражені кардіопротективні ефекти в умовах гіпоксії та метаболічного стресу, запобігаючи апоптозу та гіпертрофії. Уперше описано FoxO1-залежний механізм антиапоптичної дії метформіну в Н9С2 клітинах [40]. Було показано, що тривале лікування метформіном після серцевої ішемії-реперфузії в мишей без метаболічних порушень не тільки запобігає кардіальному ремоделюванню, а й репрограмує експресію фетальних генів, які піддаються дисрегуляції внаслідок цих патологічних змін у міокарді. Зокрема, препарат попереджує ап-регуляцію прогіпертрофічного BNP гена, зменшує запалення в зоні інфаркту шляхом даунрегуляції гена та глікопротеїну CD68, інгібує синтез фіброзної тканини завдя- ки пригніченню експресії прогіпертрофічних генів, відповідальних за продукцію гладеньком'язового актину $\alpha$ та колагену III типу [40].

Кардіопротективні властивості метформіну підтверджено в щурів з ізопротеренол-індукованим ураженням серця. 3'ясовано, що препарат запобігає гіпертрофічному та фібротичному ремоделюванню міокарда, знижуючи рівень BNP у сироватці крові як у разі нормальної маси тіла, так й ожиріння.

\section{Висновок}

Отже, аналіз результатів досліджень свідчить про те, що протидіабетичний препарат метформін проявляє виражені кардіопротективні ефекти in vivo та in vitro в умовах стресу, захищаючи міокард від гіпертрофічного, апоптичного, фібротичного ремоделювання та запалення. Механізми, завдяки яким метформін проявляє захисну дію на кардіоміоцити, потребують подальшого дослідження. Особливу увагу варто приділяти впливу метформіну на молекулярні мішені та сигнальні шляхи, залучені до процесів ремоделювання міокарда, зокрема, на експресію фетальних генів.

1. Diabetic cardiomyopathy: Pathophysiology, diagnostic evaluation and management. J. M. Pappachan, G. I. Varughese, R. Sriraman, G. Arunagirinathan. World J. Diabetes. 2013. V. 4 (5). P. $177-$ 189.

2. Causes and characteristics of diabetic cardiomyopathy. J. Wang, Y. Song, Q. Wang, P. M. EP. Kralik. Rev. Diabet. Stud. 2006. V. 3 (3). P. 108-117.

3. Metformin therapy in diabetes: the role of cardioprotection. E. Saloua, A. Gerard, N. Rongen P. Riksen. Curr. Atheroscler. Rep. 2013. V. 15 (4). P. 314-330.

4. Matthews D. R., Neil HAW. 10-Year Follow-up of Intensive Glucose Control in Type 2 Diabetes. N. Engl. J. Med. 2008. V. 359. P. 1577-1589.

5. Metformin for obesity in children and adolescents: A systematic review. H. P. Min, S. Kinra, K. J. Ward et al. Diabetes Care. 2009. V. 32 (9). P. 1743-1745.

6. Diabetes Prevention Program Research Group. Reduction in the incidence of type 2 diabetes with lifestyle intervention or metformin. N. Engl. J. Med. 2002. V. 346 (6). P. 393-403.

7. Амбросова Т. М. Ефективність застосування метформіну при цукровому діабеті 2-го типу: кардіоваскулярні, протективні та метаболічні ефекти. Експериментальна і клінічна медицина. 2013. T. 3 (60). C. 35-40.

8. Muralidaran $Y$, Viswanathan P. Diabetic Cardiomyopathy: A New Perspective of Mechanistic Approach. J. Diabetes Metab. 2015. V. 6 (10). P. 1-5.

9. Zhi Y. F., Prins J. B., Marwick T. H. Diabetic cardiomyopathy: Evidence, mechanisms, and therapeutic implications. Endocr. Rev. 2004. V. 25 (4). P. 543-567.

10. Diabetic Cardiomyopathy: Insights into Pathogenesis, Diagnostic Challenges, and Therapeutic Options. A. Aneja, W. H. W. Tang, S. Bansilal et al. Am. J. Med. 2008. V. 121 (9). P. 748-57.

11. Hyperglycemia-induced apoptosis in mouse myocardium: Mitochondrial cytochrome c-mediated caspase-3 activation pathway. L. Cai, W. Li, G. Wang et al. Diabetes. 2002. V. 51 (6). P. 1938-1948.

12. Van De Weijer T., Schrauwen-Hinderling V. B., Schrauwen P. Lipotoxicity in type 2 diabetic cardiomyopathy. Cardiovasc. Res. 2011. V. 92 (1). P. 10-8. 
13. Oxidative stress-dependent impairment of cardiac-specific transcription factors in experimental diabetes. M. Aragno, R. Mastrocola, C. Medana et al. Endocrinology. 2006. V. 147 (12). P. $5967-$ 5974.

14. Mortality from coronary heart disease in subjects with type 2 diabetes and in nondiabetic subjects with and without prior myocardial infarction. S. M. Haffner, S. Lehto, T. Rönnemaa et al. N. Engl. J. Med. 1998. V. 339 (4). P. 229-234.

15. Influence of diabetes mellitus on clinical outcomes following primary percutaneous coronary intervention in patients with ST-segment elevation myocardial infarction. L. O. Jensen, M. Maeng, P. Thayssen et al. Am. J. Cardiol. [Internet]. 2012. V. 109 (5). P. 629-35. http://dx.doi.org/10.1016/j. amjcard.2011.10.018.

16. Dipeptidyl peptidase-4 inhibitor improves cardiac function by attenuating adverse cardiac remodelling in rats with chronic myocardial infarction. T. Inthachai, S. Lekawanvijit, S. Kumfu et al. Exp. Physiol. 2015. V. 100 (6). P. 667-679.

17. Gjesdal O., Bluemke D. A., Lima J. A. Cardiac remodeling at the population level-risk factors, screening, and outcomes. Nat. Rev. Cardiol. [Internet]. 2011. V. 8 (12). P. 673-685. http://dx.doi. org/10.1038/nrcardio.2011.154.

18. Frangogiannis N. G. Regulation of the inflammatory response in cardiac repair. Circ. Res. 2012. V. 110 (1). P. 159-173.

19. CCR5 signaling suppresses inflammation and reduces adverse remodeling of the infarcted heart, mediating recruitment of regulatory T cells. M. Dobaczewski, Y. Xia, M. Bujak, C. FN. GonzalezQuesada. Am. J. Pathol. 2010. V. 176 (5). P. 2177-2187.

20. Essential role of Smad3 in infarct healing and in the pathogenesis of cardiac remodeling. M. Bujak, G. Ren, H. J. Kweon et al. Circulation. 2007. V. 116 (19). P. 2127-2138.

21. Cohn J. N., Ferrari R., Sharpe N. Cardiac remodeling-concepts and clinical implications: A consensus paper from an International Forum on Cardiac Remodeling. J. Am. Coll. Cardiol. 2000. V. 35 (3). P. 569-582.

22. Hypertrophy of the Heart: A New Therapeutic Target? N. Frey, H. A. Katus, E. N. Olson, J. A. Hill Circulation. 2004. V. 109 (13). P. 1580-1589.

23. Intense metabolic control by means of insulin in patients with diabetes mellitus and acute myocardial infarction (DIGAMI 2): Effects on mortality and morbidity. K. Malmberg, L. Rydén, H. Wedel et al. Eur. Heart J. 2005. V. 26 (7). P. 650-661.

24. Orogo A. M., Gustafsson $\AA$. B. Therapeutic targeting of autophagy potential and concerns in treating cardiovascular disease. Circ. Res. 2015. V. 116 (3). P. 489-503.

25. Cardiac autonomic neuropathy in diabetes: A predictor of cardiometabolic events. A. I. Vinik, C. Casellini, H. K. Parson et al. Front Neurosci. 2018. V. 12 (AUG). P. 1-11.

26. Pop-Busui R. Cardiac autonomic neuropathy in diabetes: A clinical perspective. Diabetes Care. 2010. V. 33 (2). P. 434-441.

27. Balcıoğlu A. S., Müderrisoğlu H. Diabetes and cardiac autonomic neuropathy: Clinical manifestations, cardiovascular consequences, diagnosis and treatment. World J. Diabetes. 2015. V. 6 (1). P. 80-91.

28. Брюхова О. В., Маньковський Б. М. Структурні зміни міокарда у пацієнтів з цукровим діабетом 2 типу та кардіальною автономною нейропатією. Проблеми ендокринної патології. 2018. V. 1. P. 16-21.

29. Aaron I. Vinik, Erbas T. Diabetic autonomic neuropathy. Inhandb Clin. Neurol. 2013. V. 117. P. $279-94$.

30. Association of hyperglycemia with reduced heart rate variability (The Framingham Heart Study). J. P. Singh, M. G. Larson, C. J. O'Donnell et al. Am. J. Cardiol. 2000. V. 86 (3). P. 309-312.

31. Effect of Metformin on mortality in patients with heart failure and type 2 diabetes mellitus. J. M. Evans, A. S. Doney, M. A. Al Zadjali et al. Am. J. Cardiol. 2010. V. 106 (7). P. 1006-1010.

32. Metformin use and mortality in ambulatory patients with diabetes and heart failure. D. Aguilar, W. Chan, B. Bozkurt et al. Circ. Heart Fail. 2011. V. 4 (1). P. 53-58.

33. Metformin therapy and prognosis of patients with heart failure and new-onset diabetes mellitus. S. P. Romero, J. L. Andrey, A. Garcia-Egido et al. Int. J. Cardiol. 2013. V. 166 (2). P. 404-412.

34. Comparative safety and effectiveness of metformin in patients with diabetes mellitus and heart failure systematic review of observational studies involving 34000 patients. D. T. Eurich, D. L. Weir, S. R. Majumdar et al. Circ. Heart Fail. 2013. V. 6 (3). P. 395-402.

35. UK Prospective Diabetes Study Group. Effect of intensive blood-glucose control with metformin on complications in overweight patients with type 2 diabetes (UKPDS 34). Lancet. 1998. V. 352 (Sep 12). P. 854-865.

36. Effects of metformin versus glipizide on cardiovascular outcomes in patients with type 2 diabetes and coronary artery disease. J. Hong, Y. Zhang, S. Lai, G. Ning. Diabetes Care. 2014. V. 37 (1). P. 19-20. 
37. Metformin inhibits isoproterenol-induced cardiac hypertrophy in mice. H. N. Cha, J. H. Choi, Y. W. Kim et al. Korean J. Physiol. Pharmacol. 2010. V. 14 (6). P. 377-384.

38. Metformin attenuates pressure overload-induced cardiac hypertrophy via AMPK activation. Y. N. Fu, H. Xiao, X. W. Ma et al. Acta Pharmacol. Sin. 2011. V. 32 (7). P. 879-87.

39. Metformin Protects H9C2 Cardiomyocytes from High-Glucose and Hypoxia/Reoxygenation Injury via Inhibition of Reactive Oxygen Species Generation and Inflammatory Responses: Role of AMPK and JNK. M. Hu, P. Ye, H. Liao et al. J. Diabetes Res. 2016. V. 2016. P. 1-6.

40. Metformin protects the heart against hypertrophic and apoptotic remodeling after myocardial infarction. H. Loi, F. Boal, H. Tronchere et al. Front. Pharmacol. 2019. V. 10. P. 154.

41. Metformin affects macrophages' phenotype and improves the activity of glutathione peroxidase, superoxide dismutase, catalase and decreases malondialdehyde concentration in a partially AMPKindependent manner in LPS-stimulated human monocytes/macrophages. Ł. Bułdak, K. Łabuzek, R. J. Bułdak et al. Pharmacol. Reports. 2014. V. 66 (3). P. 418-29.

42. Metformin inhibits monocyte- to-macrophage differentiation via AMPK-mediated inhibition of STAT3 activation: Potential role in atherosclerosis. S. B. Vasamsetti, S. Karnewar, A. K. Kanugula et al. Diabetes. 2015. V. 64 (6). P. 2028-2041.

43. Mitochondrial metabolism mediates oxidative stress and inflammation in fatty liver. S. Satapati, J. D. Browning, C. Shawn et al. J. Clin. Invest. 2015. V. 125 (12). P. 4447-4462.

44. Metformin inhibits the production of reactive oxygen species from NADH: Ubiquinone oxidoreductase to limit induction of interleukin-1 $\beta$ (IL-1 $\beta$ ) and boosts interleukin-10 (IL-10) in lipopolysaccharide (LPS)-activated macrophages. B. Kelly, G. M. Tannahill, M. P. Murphy, LAJ. O'Neill. J. Biol. Chem. 2015. V. 290 (33). P. 20348-20359.

45. AMP-activated protein kinase inhibits TGF- $\beta-$, angiotensin II-, aldosterone-, high glucose-, and albumin-induced epithelial-mesenchymal transition. J. H. Lee, J. H. Kim, J. S. Kim et al. Am. J. Physiol - Ren Physiol. 2013. V. 304 (6). P. 686-697.

46. Путилин Д. А., Камышный А. М. Изменения уровня экспрессии генов Glut1, mTOR и AMPK1a лимфоцитами панкреатических лимфатических узлов крыс при экспериментальном сахарном диабете. Медицинская иммунология. 2016. Т. 18 (4). С. 339-346.

47. Metformin protects against systolic overload-induced heart failure independent of AMP-activated protein kinase a2. X. Xu, Z. Lu, J. Fassett et al. Hypertension. 2014. V. 63 (4). P. 723-728.

48. New insight into metformin action: Regulation of chREBP and FOXO1 activities in endothelial cells. X. Li, K. L. Kover, D. P. Heruth et al. Mol. Endocrinol. 2015. V. 29 (8). P. 1184-1194.

49. Metformin Inhibits Hepatic Gluconeogenesis Through AMP-Activated Protein Kinase-Dependent Regulation of the Orphan Nuclear Receptor SHP. Y. D. Kim, K. Park, Y. Lee et al. Diabetes [Internet]. 2008. V. 57 (February). P. 306-314. URL: http://diabetes.diabetesjournals.org/cgi/content/ abstract/57/2/306.

50. Metformin inhibits estrogen-dependent endometrial cancer cell growth by activating the AMPKFOXO1 signal pathway. J. Zou, L. Hong, C. Luo et al. Cancer Sci. 2016. V. 107 (12). P. 1806-1817.

51. Forkhead box transcription factor 1: Role in the pathogenesis of diabetic cardiomyopathy. V. Kandula, R. Kosuru, H. Li et al. Cardiovasc. Diabetol. 2016. V. 15 (1). P. 1-12.

52. Воротникова C. Ю. Метформин защищает гепатоциты от стресс-индуцированного апоптоза. Ожирение и метаболизм. 2015. V. 12 (4). P. 59-65.

53. Cardiovascular risk associated with the use of glitazones, metformin and sufonylureas: Meta-analysis of published observational studies. M. Pladevall, N. Riera-Guardia, A. V. Margulis et al. BMC Cardiovasc. Disord [Internet]. 2016. V. 16 (1). P. 777-780. http://dx.doi.org/10.1186/s12872-0160187-5.

54. Metformin and preservation of left ventricular function. C. P. H. Lexis, W. G. Wieringa, B. Hiemstra et al. Cardiovasc. drugs Ther. 2014. V. 28 (2). P. 163-167.

55. Metformin influences cardiomyocyte cell death by pathways that are dependent and independent of caspase-3. D. An, G. Kewalramani, J. K. Y. Chan et al. Diabetologia. 2006. V. 49 (9). P. 2174-2184.

56. Chronic metformin associated cardioprotection against infarction: not just a glucose lowering phenomenon. H. J. Whittington, A. R. Hall, C. P. McLaughlin et al. Cardiovasc. drugs Ther. 2013. V. 27 (1). P. 5-16.

57. Effects of metformin on apoptosis induced by advanced glycation end-products and expressions of caspase-3, Bax and Bcl-2 in human dermal fibroblasts in vitro. R. Pang, M. Guan, Z. Zheng, Y. Xue. J. South Med. Univ. 2015. V. 35 (6). P. 898-902.

58. Metformin attenuates cardiac fibrosis by inhibiting the TGF1-Smad3 signalling pathway. H. Xiao, X. Ma, W. Feng et al. Cardiovasc. Res. 2010. V. 87 (3). P. 504-513.

59. Metformin exerts cardioprotection in isoproterenol-induced cardiomyopathy in rats. H. Ya. Loi, B. V. Pavliuk, S. B. Kramar et al. Med. Clin. Chem. 2019. V. 4. P. 69-77. 


\section{О. М. Олещук, Г. Я. Лой \\ Механізми реалізації кардіопротективних ефектів метформіну (огляд літератури)}

У статті проведено аналіз літератури, присвяченої кардіопротективним ефектам протидіабетичного лікарського засобу - метформіну. Серцево-судинні ускладнення є найпоширенішою причиною смертності в пацієнтів з цукровим діабетом. Діабетичне ураження серця найчастіше проявляється у вигляді ішемічної хвороби серця, автономної кардіальної нейропатії та діабетичної кардіоміопатії. Діабетична кардіоміопатія характеризується апоптозом, гіпертрофією та фіброзом, а також кардіальною дисфункцією та визначається як функціональні та структурні зміни в міокарді, незалежні від судинних чи серцевих захворювань. Ішемічна хвороба серця в хворих на діабет зустрічається частіше, ніж у популяції, а наслідки інфаркту міокарда $є$ значно важчими, що пов'язано з надмірним ремоделюванням серцевого м'яза. Кардіальна автономна нейропатія є предиктором виникнення аритмій, дисфункції міокарда, а також асоціюється з підвищеним рівнем смертності.

Метформін є препаратом вибору з точки зору ефективності та безпеки для стартової фармакотерапії цукрового діабету та залишається лікарським засобом першої лінії для більшості пацієнтів. Метформін покращує чутливість рецепторів до інсуліну та зменшує інсулінорезистентність, яка є провідною патофізіологічною ланкою розвитку цукрового діабету 2 типу. Як наслідок, знижується маса тіла, гіперінсулінемія та гіперглікемія. Окрім гіпоглікемічного, він спричиняє інші важливі ефекти, зокрема, покращує кардіальну функцію та зменшує ризик інфаркту міокарда. Метформін чинить позитивний ефект на діяльність серця, що зумовлено прямим впливом на клітинний метаболізм, ендотеліальну функцію, активність тромбоцитів і гомеостаз кальцію, модулює фактори ризику атеросклерозу, підвищує толерантність міокарда до ішемії-реперфузії та попереджує розвиток серцевої недостатності. Препарат проявляє виражені кардіопротективні ефекти in vivo та in vitro в умовах стресу, захищаючи міокард від гіпертрофічного, апоптичного, фібротичного ремоделювання та запалення, репрограмує експресію фетальних генів, які піддаються дисрегуляції внаслідок цих патологічних змін у міокарді. Більшість досліджень показують, що метформін проявляє свої кардіопротективні властивості шляхом активації аденозинмонофосфат-активованої протеїнкінази, проте відомо також про незалежний від активності цього ферменту механізм дії метформіну в кардіоміоцитах. Дедалі очевиднішим стає той факт, що аденозинмонофосфат-активована протеїнкіназа є далеко не єдиною мішенню в механізмі дії метформіну. Відомо про FoxO1-залежний механізм антиапоптотичного ефекту препарату.

Тому актуальною залишається проблема пошуку молекулярних і генетичних мішеней у механізмі кардіопротективної дії метформіну, що дозволить краще зрозуміти та розширити показання до застосування даного протидіабетичного засобу.

Ключові слова: метформін, діабетична кардіоміопатія, інфаркт міокарда, кардіальна автономна нейропатія

\section{А. М. Олещук, Г. Я. Лой \\ Механизмы реализации кардиопротекторных эффектов метформина (обзор литературы)}

В статье проведен анализ литературы, посвященной кардиопротекторным эффектам противодиабетического лекарственного средства - метформина. Сердечно-сосудистые осложнения являются самой распространенной причиной смертности пациентов с сахарным диабетом. Диабетическое поражение сердца чаще всего проявляется в виде ишемической болезни сердца, автономной кардиальной нейропатии и диабетической кардиомиопатии. Диабетическая кардиомиопатия характеризуется апоптозом, гипертрофией и фиброзом, а также кардиальной дисфункцией, и определяется как функциональные и структурные изменения в миокарде, независимые от сосудистых или сердечных заболеваний. Ишемическая болезнь сердца у больных диабетом встречается чаще, чем в основной популяции, а последствия инфаркта миокарда значительно тяжелее, что связано с чрезмерным ремоделированием сердечной мышцы. Кардиальная нейропатия является предиктором возникновения аритмий, дисфункции миокарда, а также ассоциируется с повышенным уровнем смертности.

Метформин является препаратом выбора с точки зрения эффективности и безопасности для стартовой фармакотерапии сахарного диабета и остается лекарственным средством первой линии для большинства пациентов. Метформин улучшает чувствительность рецепторов к инсулину и уменьшает инсулинорезистентность, которая является ведущим патофизиологическим звеном развития сахарного диабета 2 типа. Как следствие, снижается масса тела, гиперинсулинемия и гипергликемия. Кроме гипогликемического, он вызывает другие важные эффекты, в частности, улучшает кардиальную функцию и уменьшает риск инфаркта миокарда. Метформин оказывает положительный эффект на деятельность сердца, что обусловлено прямым влиянием на клеточный метаболизм, эндотелиальную функцию, активность тромбоцитов и гомеостаз кальция, модулирует факторы риска атеросклероза, повышает толерантность миокарда к ишемии-реперфузии и предупреждает развитие сердечной недостаточности. Препарат проявляет выраженные кардиопротекторные эффекты in vivo и in vitro 
в условиях стресса, защищая миокард от гипертрофического, апоптотического, фибротического ремоделирования и воспаления, перепрограммируя экспрессию фетальных генов, подвергающихся дисрегуляции в результате этих патологических изменений в миокарде. Большинство исследований показывают, что метформин проявляет свои кардиопротекторные свойства путем активации аденозин монофосфат-активированной протеинкиназы, однако известно также о независимом от активности этого фермента механизме действия метформина в кардиомиоцитах. Все более очевидным становится тот факт, что аденозинмонофосфат-активируемая протеинкиназа далеко не единственная мишень в механизме действия метформина. Известно о FoxO1-зависимом механизме антиапоптотического еффекта препарата в кардиомиоцитах.

Поэтому актуальной остается проблема поиска молекулярных и генетических мишеней в механизме кардиопротекторного действия метформина, что позволит лучше понять и расширить показания к применению данного противодиабетического средства.

Ключевые слова: метформин, диабетическая кардиомиопатия, инфаркт миокарда, кардиальная нейропатия

\section{O. M. Oleshchuk, H. Ya. Loi \\ Mechanisms of cardioprotective effects of metformin implementation (literature review)}

In the paper, the literature dedicated to the cardioprotective effects of the antidiabetic drug metformin is reviewed. Cardiovascular complications are the most common cause of death in patients with diabetes. Diabetic heart injury usually manifests itself in the form of coronary heart disease, autonomic cardiac neuropathy and diabetic cardiomyopathy. Diabetic cardiomyopathy is characterized by apoptosis, hypertrophy and fibrosis, as well as cardiac dysfunction, and is defined as functional and structural changes in the myocardium, independent of vascular or heart diseases. Coronary heart disease is more common in diabetics than in the general population, and the consequences of myocardial infarction are much more severe, due to excessive remodeling of the heart muscle. Cardiac autonomic neuropathy is a significant predictor of arrhythmias, myocardial dysfunction, and is also associated with increased mortality.

Metformin is the drug of choice in terms of efficacy and safety for the initial pharmacotherapy of diabetes mellitus and remains the first-line drug for most patients. Metformin improves receptor sensitivity to insulin and reduces insulin resistance, which is a leading pathophysiological cause in the development of type 2 diabetes. As a result, body weight, hyperinsulinemia and hyperglycemia are reduced. In addition to hypoglycemic, it causes other important effects, in particular, improves cardiac function and reduces the risk of myocardial infarction. Metformin causes a positive effect on cardiac activity due to its direct effect on cellular metabolism, endothelial function, platelet activity and calcium homeostasis, modulates risk factors for atherosclerosis, increases myocardial tolerance to ischemia-reperfusion and prevents the development of heart failure. The drug exhibits pronounced cardioprotective effects in vivo and in vitro in stress conditions, protecting the myocardium from hypertrophic, apoptotic, fibrotic remodeling and inflammation, reprograms the expression of fetal genes which are deregulated due to these pathological changes in the myocardium. Most studies demonstrate that metformin exerts its cardioprotective properties by activating adenosine monophosphate-activated protein kinase, but it was also established that in cardiomyocytes metformin acts independently of this enzyme activity. It is increasingly evident that adenosine monophosphate-activated protein kinase is not the only target in the mechanism of metformin's action. The FoxO1-dependent mechanism of the drug's antiapoptotic effect is confirmed.

Therefore, the problem of molecular and genetic targets of cardioprotective metformin's action exploring remains relevant, which can help understand better and expand the indications of this antidiabetic drug prescribing.

Key words: metformin, diabetic cardiomyopathy, myocardial infarction, cardiac autonomic neuropathy

Надійшла: 15 вересня 2020 р.

Прийнята до друку: 2 грудня 2020 р.

Контактна особа: Лой Галина Ярославівна, асистент, кафедра фармакології з клінічною фармакологією, Тернопільський національний медичний університет ім. І. Я. Горбачевського МОзУ, буд. 1, майдан Волі, м. Тернопіль, 46001. Тел.: + 3809789752 39. Електронна пошта: loy@tdmu.edu.ua 